\title{
When is the use of L1 (Portuguese) appropriate in groups of adolescents in monolingual L2 (English) classes? A teacher-training proposal
}

\section{Rosangela Nunes de Lima}

Professora da Universidade Estadual de Alagoas, Mestre em Letras: Ensino de inglês como lingua estrangeira - PPGLL/UFAL. O presente trabalho foi realizado com o apoio do Conselho Nacional de Desenvolvimento Científico e Tecnológico $\mathrm{CNPq}$-Brasil.

Abstract: Many non-native teachers of English as a Foreign Language seem to feel guilty about using L1 in the classroom, especially with teenagers.

This work explores the need to use the adolescents' native language. It looks at theoretical aspects, authentic opportunities and contexts for teachers to feed in or teach the kind of language necessary for real communication.
Resumo:Muitos professores de inglês como língua estrangeira, nāo-nativos, sentem-se culpados por usarem o português em sala de aula. Este trabalho explora as necessidades de uso da língua materna dos adolescentes em suas salas de aula. E procura aspectos teóricos, oportunidades autênticas e contextos para que esses professores possam ensinar um tipo de linguagem necessária para uma comunicação real em lingua estrangeira.
Keywords: first language; foreign language; monolingual classes; English classrooms; adolescents's classrooms.
Palavras-chave: primeira língua; língua estrangeira; turmas monolíngũes; salas de aula de inglês; salas de aula de adolescentes. 

Many non-native teachers of English as a Second Language often seem not to know the specific moments of using L1 in the classroom, especially in teenage groups, and they also feel guilty by doing this. These teachers can easily find themselves wondering about the following questions: 1) Is it really necessary to always use English? 2) But what is the right balance between the use of English and L1 in classroom? 3) How is it possible to use more English in the class?

\section{Introduction}

Brazilian teenagers who study English as a Foreign Language (EFL) at regular Private Schools, Public Schools, and Language Centers, on the whole, come from lowerto-middle-class to well-off families and have different backgrounds. Most of the time, these teenagers come to the English class unmotivated and not wanting to learn English. They would much rather be doing something more interesting or studying some other subject they consider more important than English. They also do not realize the access English can give them to communicate with enormous numbers of people in the world who speak English, either as a first or second language.

Due to the lack of motivation, and because these teenagers may also struggle to say or write things in L2 that they do not quite know even in their first language, they present discipline problems, either insisting on speaking L1 (Portuguese) and refusing to speak L2, or on challenging their teachers or instructors by doing this.

As many people feel that education is a job which is best done, most of the time, by teachers, and these teachers being in the same monolingual situation as their students, the use of Ll can be a fundamental resource.

Focusing on the appropriate and positive use of L1 (Portuguese) in monolingual L.2 (English) classes of adolescents, this work searches for various, useful and appropriate ways of using a communicative methodology, 
which, through a designed training session and materials, can help non-native English teachers integrate selective and limited use of the L1 in L.2 classes.

\section{Objectives}

This work has been designed to clarify in part the need of the use of the adolescent student's native language in monolingual classroom of EFL Brazilian students of English as a Second Language. It looks for theoretical aspects, authentic opportunities and contexts for the teachers to feed in or teach precisely the kind of language necessary for the use of L2, as a real means of communication, in adolescents groups.

As it was said in the introduction of this work, many non-native English teachers of teenagers usually face behavior problems and lack of motivation in their classrooms when trying to get their students to communicate in L.2.

In most situations, English lessons are not very frequent, as few as two fifty-minute-classes per week, and the question of making these adolescents progress is very important for the teachers who struggle to have their students' learning and speaking in I.2, as efficiently as possible, in such a short time.

As an English teacher and a reflective professional, with experience in English language education for over 14 years in language centers, and in secondary level education at a private school, I have observed that English teachers in general use L1 (Portuguese) unnecessarily with their students. These observations helped me to discover that when adolescents speak Portuguese, the teachers do not usually encourage them to speak English but rather act as if those students did not know enough to say the kind of language that was expected to be produced at their level of English. 


\section{Training context and background}

The purpose of this work is also to present the result of an interpretive research carried out with the help of some non-native English teachers from secondary private and public schools, in Arapiraca-AL, who answered a questionnaire of identification and participated in a training session which had already been thought and set.

The majority of the teachers do not have the opportunity to choose the book they will use in their classrooms, this is a choice of the principals of the schools they work for, who in general impose a student's book that does not reflect the students' needs.

\subsection{The teachers' qualifications and background}

Most of the teachers have been teaching English for more than four years, at private and public schools, and none of them have a B.A or an M.A in the teaching of English as a foreign language. Two of them have been taking the Letters course at University. One of them is majored in Mathematics. And some of them have some kind of Certificate taken at an English Language school.

The teachers' ages are from 20-32, and they come from lower-to-middle-class backgrounds. Most of them have studied English in private language schools.

\section{Background to the content area of the training session and how it relates to current thinking in ELT (English Language Teaching)}

Language is a means of communication. It is not used in a vacuum but by one person to another to convey information, emotion or attitude; to ask for directions; to do business; to describe people, things etc.

Languages have been studied more than ever before. Methods and approaches of learning them are changing broadly, reflecting a commitment to finding more efficient and more effective ways of teaching languages. 
It has been a practical concern throughout history. And Almeida Filho (1993), a Brazilian Applied Linguist, says that a foreign language carries with it a complex concept, which a language teacher should be aware of, and should also reflect about it in their language teaching methodology.

Many theoreticians have worked hard on research to provide a background for discussion of new ideas on how to teach English as a foreign language. These ideas are based on different theories of how people learn a foreign language.

The starting point of this study is the fact that the English teachers follow different methods and have obstacles to getting their teenager students speaking in English during class. These teachers find difficulties in avoiding the use of the students' first language. They feel sometimes guilty for having used L1 in the class, as well. This leads to a discussion that reflects mostly some of the routines of a monolingual class, where the teacher also knows the students' language. The questions that are raised by teachers might be the following:

a) Is it really necessary to always use English?

It is important to emphasize that this work has been focusing adolescent students of English. Some research findings to early foreign language instruction say that older foreign language learners make more rapid progress than younger learners, because they have advantages of intellectual maturity insights into language and experience in studying a first language (FEUERSTEIN et al., 1996, p.29). As for young adolescents, they find it difficult and sometimes boring to learn English by listening and speaking it during the whole class, as I.2 (English) does not go beyond the level of mastery of the L1 (Portuguese).

This fact can cause the lack of motivation of some of the students. We should also highlight the fact that people learn languages differently, according to their ways of apprehension. 
A probable answer for the question above would be the one that we should use mainly English in the adolescent classes, not only English. Atkinson (1993, p.12), states that "If English is not the main language used in the classroom, the learners are not going to learn very much English."

The teachers should present at the beginning of a new term a set of rules for their classrooms, telling the students the reasons why it is so important the main use of English in class.

b) But what is the right balance between the use of English and L 1 in classrooms?

There are situations where the students' mother tongue is of particular use especially at lower levels, such as for giving instructions, eliciting language, checking comprehension and classroom management.

Many things can be done to help adolescent students in particular to familiarize with the classroom management and instructions given by teachers. These teachers must reinforce the meaning of that language through the use of mimic, gesture, visual and even with the help of some of the better students in class.

Some studies show that there are considerable advantages to allowing both languages in the classroom. Among them, Lewis and Hill (1990, p.35) state that:

some students will have ideas but not the English to express them; others will have the English but not the ideas. Permitting both languages - preferably in clearly defined areas - usually ensures that much of the work is more interesting, and that ultimately a higher standard of English is achieved.

Atkinson (1993, p.14) highlights some factors in which the proportions of English and L1 should depend on:

[...] the students' previous experience [...] At higher levels it should be unnecéssary, [...] But it can still 
be useful in other areas, e.g. translation of vocabulary $[\ldots]$ As the teacher gets to know the students and the students become familiar with the teacher's style, it becomes easier to do more activities entirely in English.

c) How is it possible to use more English in class? Teachers who recognize the use of the English language as a real means of communication will perceive the necessity for many genuinely interesting activities. It is possible for adolescent students of English to study material of real interest to them, and to have conversations with the ideas of their own through the target language they are learning.

Teachers should also think of what happens in the classroom, during the activities executed by the students. They must make sure that these activities reflect the nature of language and that they are really going to help students to achieve their objectives.

Some ideas:

Pair and group work - 'They can be used in almost any teaching situation, and it appears to be an appropriate solution to the problems of class size, mixed ability and student discipline. Of course the monitoring of the teachers plays an important part in these activities.

Role play dialogues - Revell (1994, p.06) defines roleplay as "an individual's spontaneous behavior reacting to others in a hypothetical situation. The essential core of the activity is understanding the situation of another person [...]". The teacher should give the student some information about his role and the characters, in order to have him "interact with others and relate his situation to theirs; and gain a greater understanding of the roles, the relationship, and, in our case, the language involved". Silveira (2002, p.55), suggests that we should use role-playing in our classes in order to give emphasis to the practice of conversation. 
Maps, menus and different materials - Revell (1994) also suggests the use of real maps, menus and many different materials to give students the opportunity to familiarize with a foreign culture and to encourage the use of the language in a more interesting and communicative way.

Use of true cognates in learning - Languages which are related and which are supposed to have had a common ancestor language are called "Proto Indo-European" languages. English and Portuguese are related to each other in this aspect. So that, there are obviously word cognates between them. Teachers should use true cognates with their students because of the similarities in form and meaning between L1 (Portuguese) and L2 (English). This could be a good opportunity for the students to enlarge their vocabulary, and get more confident when speaking in L2. Atkinson (1993, p.60) says that:

For speakers of some languages cognates are an enormously valuable resource - there are huge areas of vocabulary which are much easier to learn because of the similarities between the L1 and English. And even where this isn't true it's still worth encouraging students to be aware of and exploit those cognates which do exist.

Teachers should speak English around the school - It is sometimes difficult for the students to meet native speakers of English for them to talk to. It can be very helpful if the teachers speak to each other in English in the school setting. This would contribute to make the students realize that the target language studied is a real means of communication. It would also help teachers maintain the use of it in the classroom, according to the rules set for this.

Mime and gesture - We do not just communicate with each other with words, we use both verbal and non-verbal means, e.g. by intonation, gesture, facial expression and many others. Teachers should think that their students may 
find it interesting using nonverbal means to try to communicate in L2.

I finally decided on a training session about the use of L1 in class and how to find out better and more enjoyable ways of avoiding that happening. When I showed it to the teachers I am acquainted with, they thought it was a relevant subject to talk about and we agreed to meet in a private Institution - Previsto Cursos in Arapiraca, Alagoas, in order to discuss on the positive aspects that the use of L1 in L2 classes could have.

\section{Training Principles}

5.1. Training should be practical and relevant. It should reflect the trainee's needs, in order to help them evaluate and explore their own teaching.

5.2. The trainer should take into consideration the modes of apprehension because people learn things in different ways, they have different learning styles. If there is too much dependency on one skill, the trainees can feel demotivated, finding the training has been inappropriate to them.

5.3. The trainer should treat everyone's opinion and comments with respect. This way the trainees can be more confident as foreign language teachers and they will consequently show more interest in their teacher's training program offered by the institution.

5.4. The trainer should be always prepared for any unexpected answers and questions the trainees may present. It should be reminded that there are no right answers, but choices and alternatives.

\section{Training Plan}

\section{Aims}

To encourage participants to read and reflect on articles about the use of L1 (Portuguese) in L2 (English) classes;

To analyze the use of L1 in their classes; 
To consider the reasons FOR and AGAINST the use of L1 (good and bad aspects of the use of L1);

To develop strategies on how to use the positive aspects of the use of L1 in L2 classes.

\section{Objectives}

Trainees will be able to apply a few useful techniques when using L1 in the classroom; and they will be able to contrast the appropriate use of L1 with the unappropriate use of L1 in L2 classes.

\section{Introduction (15') T-TT - TT-TT}

Place on the board a poster with the training session title, and ask for trainees' feedback on the articles read. Elicit and talk about the subject by brainstorming critically based on their personal experiences in the classes. Establish groups of 3 or 4 . Use O.H.P. transparency with WHEN... HOW OFTEN... WHY... questions.

\section{Feedback (5') T-TT}

Write on the O.H.P. transparency their comments on the topic. Elicit from the trainees: Do they match to what they read on the articles? Praise, agree and share their summaries.

Reflection Time (5') T-TT

Keep asking trainees about their own experiences. Why does this happen in our classes? Why?

Activity 1 (15') TT-TT

Appropriate and unappropriate (aspects of the use of $\mathrm{L} 1$ in class)

a. Give trainees a handout with two questions:

1. Why the use of L1? - FOR

2. Why not the use of L1? - AGAINST

b. Get participants to work in pairs and ask them to write down 3 FOR and 3 AGAINST and then, in a bigger group, they should decide on one FOR and one AGAINST (the ones they think are the most important). 
Feedback (8') TT-T

Allow trainees to show their findings and say why.

\section{Summing up (7') T-TT}

Show trainees an O.H.P. transparency with some ideas on how to use L1(Portuguese) appropriately in L2(English) classes.

Distribute handouts with the ideas (Appendix A).

\section{Post session task}

Ask trainees to write down ideas, techniques and class rules they have on how to use L1 in L2 classes appropriately and share with the rest of the group, at the beginning of the semester or the term.

\section{Materials - Resources}

OHP transparency with the questions: WHEN...? HOW OFTEN...? WHY...?

Poster size sheets; card boards; marker pens; blue tack.

Handout (Articles on teaching monolingual classes by David Atkinson (1995), and on Teaching English as a foreign language to young learners by Feuerstein, Karee, Vital and Zerah (1996).

Handout with ideas on how to use L1 appropriately in L2 classes (Appendix A).

Handout with Activity 1 (Appendix B).

\section{Conclusion}

As an English teacher and a reflective professional, I started to observe from my own experiences the kind of problems teachers at private and public schools has been facing. They are: the unnecessary use of L1 (Portuguese) by the teachers and students; reluctant learners who feel demotivated after some time of studying a L2 (English), most of the time in a traditional method, which makes use of translation and grammar study as the main teaching and learning activities 
rather than emphasize the ability to communicate in a language (SILVEIRA, 1999).

Since every step of the training session had already been thought and set, I went on presenting it to the teachers invited, who deal with the age group in question from 11 to 16 years old. We agreed that the topic in question had been fruitfull and the personal experiences we shared were really relevant. 


\section{References}

ALMEIDA FILHO, J.C.P. Dimensões comunicativas no ensino dc línguas. 3 ed. São Paulo: Pontes, 2002.

ATKINSON, D. Teaching monolingual classes. England: Longman, 1993.

FEUERSTEIN, T. et al. Teaching English as a foreign language to young learners: The oral-aural stage. A handbook for teacher trainers. Israel, 1996.

GRANGER, C. \& PLUMB, J. Observation 1. In: Play games with English 1. London: Heinemann, 1980. p.7.

LADO, R. Language teaching: a scientific approach. New York: McGraw-Hill, Inc., 1964.

LEFFA, V.J. Making ends meet in the classroom: the attributes of the good language teacher. On line in: www.leffa.pro.br/ teachdev.htm in 06/09/2004.

L.EWIS, M.; J. Hill. Practical techniques for language teaching. England: Language Teaching Publications, 1990.

PAIVA, V.L.M.O e. Making learning meaningful. In: www.veramenezes.com/learning.htm in 11/07/2005.

PLATERO, L. Oensino de linguas estrangeiras em classes numerosas e heterogêneas. In: www.sbs.com.br/bin/etalk/ index.asp? cod=872\# in 2005.

REVELL, Jane. Teaching techniques for communicative English. London: Macmillan Press Ltda,1994.

RICHARDS, J. et al. Approaches and methods in language teaching. USA: Cambridge University Press, 1994.

Dictionary of language teaching \& applied

linguistics. UK: Longman, 1996.

SILVEIRA, M.I.M. Línguas estrangeiras: uma visão histórica das abordagens, métodos e técnicas de ensino. Maceió - São Paulo: Catavento, 1999.

O ensino da conversação em línguas estrangeiras.

Revista Leitura. Maceió: Ufal, 2001/2002. 
WIDDOWSON, H.G. O ensino de línguas para a comunicação.

Tradução José Carlos P.de Almeida Fïlho. Campinas, SP: Pontes, 1991. 


\section{APPENDIX A}

Ideas on how to use L1 (Portuguese) appropriately in L2 (English) classes:

Paired and Group work activities

It would help teachers deal with mixed ability classes.

The use of English around the school

It would help convince students that the target language (English) is a real means of communication, and it would also help teachers to maintain the use of it in the classroom.

Role Play dialogues

It would help teachers to get the students involved in the target language more spontaneously.

Maps, menus, visuals

It would give students the opportunity to familiarize with the foreign culture and use the language in a more interesting way.

The use of true cognates

It would help teachers show the students the similarities between L1 (Portuguese) and L.2 (English), and it would also help students increase their vocabulary in $\mathrm{L} 2$.

Mime and gesture

The use of non-verbal aspects of communication would help students to turn them into verbal communication in the target language.

Magazines, newspaper and articles in the target language Teacher could use some very important news that has just happened or that it is about to happen to have a brief talk in L1, then turn it into a "theme" for a whole lesson in L2 (e.g. Olympic Games). 


\section{APPENDIX B}

\section{ACTIVI'T'Y 1}

PLEASE, WRITE HERE 3 IDEAS FOR:

WHY THE USE OF L.1? WHY NOT THE USE OF L1?

FOR

AGAINST 